\title{
Artikel
}

Sarah Heinz*

\section{Beyond Sedentarism and Nomadology: Yaa Gyasi's Homegoing and the Ambivalent Desire for Home}


Abstract: Heim und Heimat sind auratische Begriffe, die häufig mit positiven Emotionen und Erlebnissen wie Behaglichkeit, Wärme oder Sicherheit verbunden werden. In solchen Assoziationen wird Heim/at zu einem stabil existenten Ort, einer organischen Gemeinschaft und einem angeborenen Gefühl, d.h. zu einer angeblich natürlichen Erfahrung, die von außen bedroht werden kann. Solch eine ,sesshafte' Metaphysik sieht Mobilität als Pathologie oder Bedrohung und lehnt Heimatlosigkeit, Bewegung und alternative Modelle von Heim/at ab. Diese Konzepte von Heim/at sind von nomadologischen Ansätzen hinterfragt worden. Heim/at wird hier als gefährliche Fantasie und Ideologie verabschiedet, während eine radikale Heimatlosigkeit, Mobilität und nomadische Subjektivität zu einer Quelle für Widerstand gegen Essentialismus und staatliche Kontrolle werden.

Diese binären Oppositionen haben zu Aporien in der Diskussion um Heim und Heimat geführt, die der Artikel nachzeichnet, um, angelehnt an Brahs Konzept des ,homing desire' (1996), anhand der Lektüre von Yaa Gyasis Roman Homegoing (2016) einen dritten Weg zur Konzeptualisierung von Heim/at vorzuschlagen. Anhand der beiden Protagonistinnen Effia und Esi als repräsentativen Beispielen für die ambivalente Sichtweise des gesamten Romans wird verdeutlicht, dass Effias Lebensgeschichte organische, sesshafte Sichtweisen auf Heim/at kritisch kommentiert, während Esis Geschichte aufzeigt, dass die Glorifizierung von Nomadismus und radikaler Heimatlosigkeit ebenso problematisch sein können. Für beide Protagonistinnen und ihre Nachkommen ist Heim und Heimat flüchtig, fluide und problematisch, gleichzeitig aber auch eine Sehnsucht und ein unerfüllbarer Wunsch.

Home is an auratic term that is often connected to positive feelings and experiences like comfort, warmth, or safety. In such associations, home is set up as a pre-existing space, an organic community, and an inborn feeling, i.e. an allegedly natural experience that can become threatened by hostile outside forces. Such a sedentarist metaphysics sees mobility as a pathology or threat and rejects both homelessness and alternative notions of home. However, ideas of home have been 'mobilised' in nomadological approaches to home and mobility. Here, home is reassessed as a dangerous fantasy, and a radical homelessness and nomadic subjectivity turns into a progressive source of resistance to essentialist sedentarism and state control.

This binary opposition has led to certain impasses in the discussion of home that the article traces, to then propose a third way of conceptualising home in a close reading of Yaa Gyasi's novel Homegoing (2016) along the lines of Brah's notion of a 'homing desire' (1996). Using the initial two protagonists, the two sisters Effia and Esi, and their respective chapters as representative examples for the novel as a whole, the close readings show that Effia's story critically comments on organic, sedentarist notions of home, while Esi's story underlines that celebrations of nomadism and homelessness are equally problematic. For both characters and their descendants, home is elusive, fluid, and far from unproblematic, but at the same time, home is something longed for and desired.

Keywords: Home; mobility; homing desire; Yaa Gyasi, Homegoing; sedentarism vs. nomadology; family

*Prof. Dr. Sarah Heinz, Universität Wien, Institut für Anglistik und Amerikanistik, Professur für Englische und Anglophone Literaturen, E-Mail: Sarah.Heinz@univie.ac.at

In recent years, I have taught several seminars and lectures on home and homeland and have used aspects of home in workshops or summer schools. One thing I always start with is to ask the participants what they associate with the word 'home' without much explaining in what sense or context we will talk about the notion. Reactions are surprisingly consistent, even across national settings and generations: For the majority of people, home is safety, comfort, and a private space. Home is also associated with community, family, origins, or their birthplace or hometown 
where their parents might still live. And finally, home is connected to their identity and agency. It is a space where they can be themselves, or, as one participant phrased it recently, "home is where the dog licks my face." ${ }^{\prime \prime}$

What becomes obvious in all of these associations is that home, more often than not, is an auratic and highly positive term: it glows, it promises something, and it connects us with our sense of self, our past, and the people we love. Although many participants are not surprised to hear that research has often focused on the negative aspects of home, e.g. domestic violence, a lack of agency, power politics, and hierarchies, individually home is seen as a refuge and a place of belonging. I want to concentrate on such discourses of belonging and their contestation in the following. The literary analysis focuses on Yaa Gyasi's novel Homegoing, published in 2016, a family story that follows two sisters from the Gold Coast, now Ghana, and the life stories of their descendants in both America and Africa across seven generations.

My thesis is that Gyasi acknowledges that home is a human desire and that ideas of belonging and origins cannot simply be discarded or dismissed. However, the novel also makes clear that home does not simply exist and that it is neither organic nor unproblematic. It rather is a fluid experience and constantly in the making, and it can trigger both positive and negative feelings. The novel can thus be helpful in reframing reductive debates around home that have frequently been stuck between a celebration of homelessness and mobility or a conservative glorification of essentialist and defensive notions of home. In its ambivalent depiction of home, the novel therefore defies what David Morley has termed "the sterile opposition often posed between nomadological and sedentarist perspectives" (2017, 9). Using the initial two protagonists, the two sisters Effia and Esi, and their respective chapters as representative examples for the novel as a whole, my close readings show that Effia's story critically comments on organic, sedentary notions

1 I would like to thank the participants of my courses and workshops on home held over the last few years at the universities of Vienna and Mannheim, for their ideas, lively debate, and creativity around the issue of home and homeland. I specifically thank the participant who allowed me to use the quote cited above, taken from one of their creative writing exercises. of home, while Esi's story underlines that wholesale celebrations of nomadism and (an equally essentialist) homelessness are also problematic. For both characters (and their descendants in the later chapters), home is elusive, fluid, and far from unproblematic, but at the same time, home is something longed for and desired.

In order to contextualise the critical reframing of home in the novel, the paper will first sketch the two central oppositions outlined above: sedentarist celebrations of home as stable and natural vs. nomadic rejections of home and celebrations of homelessness. In my close readings, I will then propose a conceptualisation of home that mediates between these two seemingly exclusive interpretations, using Avtar Brah's notion of a 'homing desire' (1996). This concept stresses that home and having a home is a desire that many human beings might share, but that this home does not simply or even naturally exist. In this sense, home can never be fixed or essentialised as sedentarist discourse has attempted to do, as I will now show.

\section{Being (at) Home: Sedentarist Idealisations of Home and Homeplaces}

In spite of the intuitive ease with which most people approach the idea of home, it is notoriously tricky to define as soon as you look closer. Home is a multidimensional term that may refer to physical structures like a house, social units like a family, a place of origins, concrete practices, or affective ties. It is a place, a performance, an imaginary, a feeling, or a sense of self, all at the same time (cf. Mallett 2004, 62-89). Home is also a scalable concept that may start with my mind or body as home, a house as my home, and end with a nation or even the globe as home (cf. Marston 2000, 219-242). Scholars have therefore imagined these scales of home as concentric circles (cf. Hollander 1991, 31-49). The multiple scales and dimensions of home can explain the terminological and conceptual vagueness of home, but they can also account for the relative effortlessness with which common-sense understandings of home often conflate house and home, home and homeland, or home, family, and identity. 
Such "complexity and layered meanings of 'home'" can be connected to the issue of the translatability of terms like 'Heimat,' words that are often surrounded by a "certain mystery" (King 2016, 247). It has been claimed that the term 'Heimat' cannot be translated, e.g. by words like the English 'home', because 'Heimat' is said to contain "German-specific" ideas that are not contained in the other language (Cunningham et al. 2018, 146), a claim that often entails keeping the German term in italics or inverted commas (as for example in Tuan 2012, 230). There is a certain legitimacy to such claims, as direct translations of a term like 'Heimatfilm' as 'home movie' make more than clear. However, the idea that the affective load of 'Heimat' is completely untranslatable and that the emotional weight of the term is German-specific is problematic. The English term 'home' is as affectively loaded and multidimensional as the German 'Heimat', and both terms contain the conflation of individual home and national homeland. This is shared by many similar terms in other languages, e.g. the Albanian 'shtëpi,' which means both a physical dwelling and "the emotional feelings attached to something which is less tangible" (King 2016, 247). Although a direct and comprehensive translation of a term like 'Heimat' without losing any cultural and emotional aspects is impossible, this more general problem of translation per se should not inhibit us from seeing similarities and overlaps in notions of home in other languages and its affective and multidimensional character.

What this discussion of definitions and translations of home outlines is that the term is a kaleidoscope of dimensions, scales, and meanings. Nevertheless, what many associations share is their seeming stability and boundedness and their sense of home as a place of belonging. Morley describes such understandings of home as part of a "sedentarist metaphysics" that focuses on being there, on proximity (both physical and emotional), rather than on movement:

In this cosmology, physical contiguity and the strength of social and emotional connections have largely been assumed to be equivalent, so that all that is physically close at hand also feels familiar. $(2017,59)$

This sense of home can take on "rather cosmic proportions," as for example in Martin Heidegger's notion of dwelling as a place "that one's life emerges in and (in the larger sense) to which it returns at death. So being in (and from) a place integrates one's life" (Fox 2016, 21, emphasis in original; see also Heidegger 1975). Heidegger here connects the linguistic roots of bauen, the act of building, with buan, to dwell, and, finally, with a human's self or being, in German bin or bist. He thus creates an intense, organic relation between dwelling and identity that, in turn, enables humans to build and create homeplaces: "Heidegger develops the essential continuity of being, building, dwelling, and thinking." (Hofstadter 1975, xiii, emphasis mine; see also Blunt and Dowling $2006,3-5)$. The logical flipside of such organic notions of home is, then, that "all forms of mobility, which 'disembed' individuals from their local communities, have been seen to undermine social cohesion" and have been associated with danger, pollution, and destruction (Morley 2017, 59). In a famous definition, George therefore defines home as "the place where one is in because an Other(s) is kept out" (1996, 27; emphasis in original; see also Morley 2000, 31-41).

The watercolour "The Sinews of Old England" by George Hicks from 1857 provides a good starting point for an unpicking of such sedentarist concepts of home because it connects the home's stability and familiarity to a genetic sense of belonging and an authentic, rooted, moral way of life. We see a young family in front of their well-furnished, tidy home. The young wife adoringly looks up at her husband, who in turn looks beyond the frame of the painting and past us as the viewers. Through his position within the frame of the picture and through his posture, it is obvious that he is the most important person of this domestic scene, but that he belongs to the world beyond it. Next to them, the couple's blond child is already being trained in the power relations of home, holding a shovel and lovingly clinging to the father's trouser leg. All three figures stand on the home's threshold as the border between the feminised world of household and childcare and the allegedly masculine public sphere (cf. Blunt and Dowling 2006, 140). Thus, home literally is a background for the whole scene, yet the male's gaze is directed away from it.

The picture's title connects this tidy and carefully gendered scene to the nation: this home is an ideal version of England, and the sinews to defend and build it are the white male's as a 


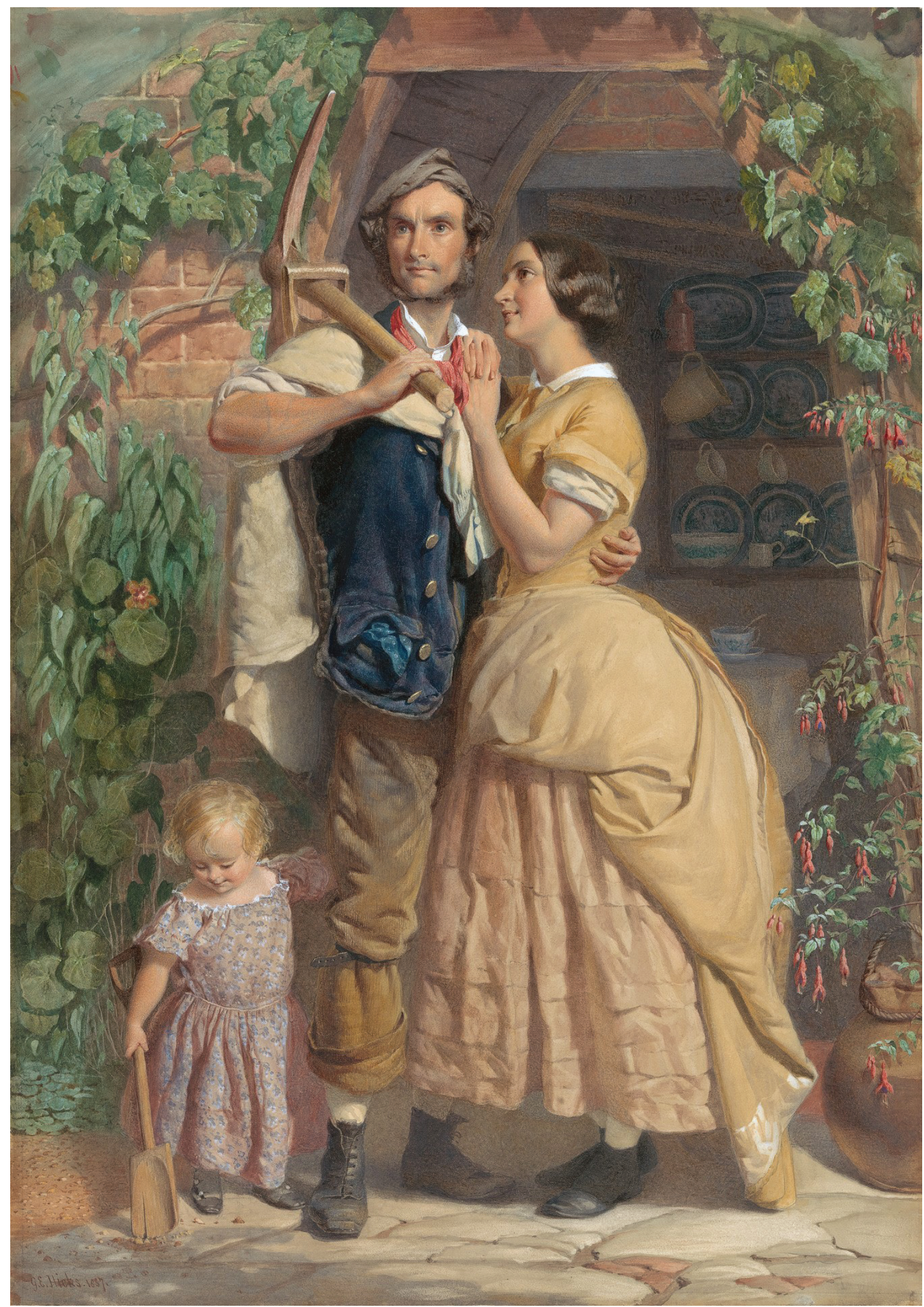

Illustration 1: George Hicks, "The Sinews of Old England" (1857, Yale Center for British Art) 
father and husband. His wife on the other hand has equally proven that she can fulfil her part of the national deal: she is young, fertile, and white, and can thus provide for the continuity of this ideal England in her white children. Man's creative, public, and physical work is thus, again organically, connected to women's reproductive work and framed by the private homespace. It may come as no surprise, then, that the centre of the picture is the place where the couple's hips meet. The painting's motif of the 'fated' roles within the family illustrates that "[t]he family home appears as an integral location for imagining the nation as a whole" (Blunt and Dowling 2006, 140). The painting thus shows how images of the individual family home have been instrumentalised to connect both larger communities and individuals to abstract entities like a nation, first and foremost emotionally. Already in its etymology, the nation is closely linked to metaphors of genetic, biological, or familial links and thus to naturalised notions of the family home. 'Natio' derives from the Latin 'to be born,' and different nations were referred to as breeds, stocks, or races (cf. McClintock 1997, 90f.; Loomba 2002, 22-26). This concept of the nation as genetic fate and domestic genealogy, as something you are born with, creates a seemingly natural link between the individual citizen and the nation, the nation's past and its future, and this link is seen as inescapable and unchosen (cf. Anderson 2006, 143).

Such organic, biological imaginaries and their mapping of the family home and the homeland make it unnecessary to explain why exactly people's feelings for their homeplaces should also 'naturally' be how they relate to their national or other collective communities. At the same time, this discourse of home as organic belonging also shows that "[h]ouses are assumed to become homes because they provide and become the environment within which family relationships - close, private, and intimate - are located" (Bowlby/Gregor/ McKie 1997, 344). A house without a family seems to be no real home, and a community devoid of kinship ties does not seem to be a homeland. This can then be extended to an individual's role within the home and the homeland, turning the family into the idealised place of producing ideal citizens: "A house identified with the self is called a 'home', a country identified with the self is called a 'homeland'"' (Tabor 1998, 218; qtd. in Morley 2000, 266).
The naturalised trope of the family home thus offers an extremely powerful tool for explaining and sanctioning social, cultural, and political hierarchies and sometimes radical and violent actions against those deemed to threaten this home. Such a moral evaluation of home and of close, familiar human relations as the only truly authentic form of community is typical for sedentarist discourses, and it has led cultural critics like Leavis and Thompson, the Chicago School, or sociologists like Simmel or Sennett towards multiple condemnations of alternative modes of being and the allegedly detrimental effects of modernisation, e.g. in their interpretation of urbanisation as alienated placelessness, threatening 'foreign' influences as endangering formerly 'organic communities,' or mobility (and mobile populations) as pathological and demoralising (cf. Morley 2017, 60). What all such evaluations of mobility and placelessness share, no matter their sometimes radically different political orientation, is their nostalgia for a space and time in which home was unquestioned and in which people were 'naturally' connected to each other and, therefore, also to themselves.

\section{Contesting Organic Notions of Home: Nomadology and the Celebration of Homelessness}

Such sedentarist notions of home illustrated by a painting like "The Sinews of Old England" have been heavily criticised. Research as well as political activists or anti-colonial movements have shown that issues of agency, dependence, and power are central to how home is used to engender a problematic and defensive sense of identity and unity. Such critiques of organic ideas of belonging and Heimat have, specifically in their postmodern form, tended towards "an idealization of all that is nomadic. There, mobility is identified with practices of transgression and resistance" (Morley 2017, 61). From Thomas Hobbes' "identification of unfettered movement with the liberty of the modern individual" to the more radical celebration of a nomadic metaphysics in Deleuze and Guattari and their "focus on the nomad and/or the rhizomatic as evading the repressive control of the state," stable notions of home have been rejected as dull, conservative, 
dangerous, and reactionary (Morley 2017, 61). The "nomadic subject" becomes the new paradigm after the crisis of modern subjectivity (cf. Braidotti 2011). In this vein, Deleuze and Guattari develop a nomadology as the much-needed antidote to sedentarist discourses and present it as the opposite of history (cf. 1987), and Grossberg talks about a "politics of dislocation" as the prime means to think about modalities of belonging and attachment that are still possible in the contemporary world (1996, 185). Bauman, more sceptical of its potential negative outcomes but sure of its inevitability, similarly identifies fluidity as the principal source of strength in and central characteristics of what he terms "liquid modernity" (2012). Specifically in the context of studies of new media like the mobile phone or new networks of electronic communication, it has been claimed that we have developed a "place polygamy" or even a deterritorialised placelessness that has detached us from the physical world and material geographies that have been so crucial for sedentarist notions of home and the identity of being and dwelling (cf. Morley 2017, 10).

In these nomadological approaches, home turns into a phantasmagoria, a conservative imaginary, or even into a dangerous (but always made-up) tool of ideologies and state control. Homelessness and migrancy, a highly negative stigma in sedentarist ideals of home, now become new modes of being and of resistance, in and of themselves liberating and progressive. Instead of being bounded spaces with fixed, even natural borders, home and homelands only come into being because there are people and communities transgressing them. This focus has been especially pronounced in studies of transnational homes and migration. Researchers have asked questions about whether and how a place can become home, what it means to be at home, and how the loss or leaving of a familiar space affects communities, individuals, but also their literary imaginaries of old and new homeplaces (cf. Ahmed 2000; Al-Ali and Koser 2002; Ahmed et al. 2003). Thomas Nail has termed this "kinopolitics," a politics of movement, and in his reading, the migrant turns into the primary or even constitutive figure of human history: "kinopolitics is the reinvention of political theory from the primacy of social motion instead of the state" (Wolters 2015, n.pag.; cf. Nail 2015).
This nomadological focus on the uses and abuses of home and the role of mobility has enabled a new sensibility for the processes through which sedentarist notions of home are developed and authenticated. The question that has been increasingly posed in research is not what home is, but rather how and why notions of home are brought into being and how they are changing across time, space, and between cultures and communities (cf. Blunt and Dowling 2006, 88). Homeplaces and practices, social relations, and the complex feelings we attach to them here are assessed as sites upon which ideas and ideals of identity and community are acted out without assuming that these home arrangements are natural or unchanging. Rather than a private space or respite from social norms, home is seen as "intensely political both in its internal relationships and through its interfaces with the wider world over domestic, national and imperial scales" (Blunt and Dowling 2006, 142). The same holds true for literary imaginings of home: "Imagining a home is as political an act as is imagining a nation." (George 1996, 6). In this logic, home does not exist and is definitely neither organic nor natural. To look at how it is brought into being can therefore enable us to unpick the ideological baggage that imaginaries of home have been made to bear.

However, the nomadological celebration of mobility and homelessness has also led towards certain impasses. Referring to Ahmed's critique of the uncritical use of migrancy as an overly generalised metaphor or even an ontological condition (1999), Morley explains:

The problem here $[\ldots]$ is that this generalization of
mobility as a form of ontological liberation from reified
identities is proposed as a kind of 'ethics of trans-
gression' that improperly universalizes all forms of
estrangement. Evidently, in so doing, it erases all the
important specificities and differences between those
who travel, disregarding the diversity in the extent of
their travel, the way they do so and why, and whether
or not they have control over their mobility. $(2017,63)$

The metaphorisation of migrancy and the flattening of differences between specific, concrete, and contextualised forms and experiences of mobility ignore the profoundly different effects of forms of mobility and migrancy and fail to answer questions about who travels or has access to mobil- 
ity, when, how, and under what circumstances people travel, and what agency they have over their movement. Studies on the loss and destruction of home have shown how painful and problematic experiences of movement can be. Here, homelessness can engender a loss or lack of agency, e.g. towards the state or the multinational companies that evict people and communities, rather than creating a position of resistance and power (cf. Porteous and Smith's influential study on domicide and the global destruction of home, 2001).

In the context of such impasses, Avtar Brah's concept of a "homing desire" and the role of the diasporic experience is an important intervention in the debate surrounding the opposition of sedentarist and nomadological notions of home. Similar to nomadological approaches, Brah inverts the usual perspective onto home, seeing it come into being through movement, leaving, and loss. This shift radically changes how home is defined. Instead of being something from which we start, it is something that we never reach, something that never exists as a stable place or sense of belonging. Similar to Nail's idea of kinopolitics, Brah uses the diasporic experience and its reassessment of stable senses of home and borders as a means to "think through" them $(1996,198)$, turning diasporas into "an ensemble of investigative technologies" $(1996,197$, emphasis in the original).

However, Brah also acknowledges home as something that humans might still desire. She argues that "the concept of diaspora offers a critique of discourses of fixed origins, while taking account of a homing desire which is not the same thing as desire for a 'homeland'." (1996, 180). Home is multi-locational, ambivalent, and a fiction. Nevertheless, a space and a community can become home, even if they never just are home. Consequently, there is an important "difference between 'feeling at home', and staking claim to a place as one's own," and Brah insists on the need to not lose sight of the specific contexts, moments, and circumstances in which choices about home are made $(1996,193)$. In a final move, Brah uses this multiple, fluid, and processual approach to home as a means to re-define identity as "always plural, and in process" without rejecting the notion of identity completely (Brah 1996, 198). This interpretation of the experience of diaspora shows that home and self are about both routes and roots (cf. Gilroy 1993; Clifford 1997).

The following close readings of the life stories in Gyasi's Homegoing will now focus on this duality of routes and roots and on the elusive qualities of home in its protagonists' ambivalent homing desires, showing how the novel as a whole can help to reframe the often binary debates around sedentarism and nomadology outlined above.

\section{Points of Origin: Absent/ Present Mothers and the Ambivalence of Home}

Gyasi's novel is preceded by an Akan proverb: "The family is like the forest: if you are outside it is dense; if you are inside you see that each tree has its own position." (HG, n.p.). ${ }^{2}$ This proverb frames the novel's stories about home in terms of family, describing it by a metaphor taken from nature. The 'family as forest' metaphor, however, is not used to stress the essential, in-born qualities of domestic ties. The proverb rather focuses on how 'the family' does not simply exist. It is a matter of perspective: it seems to be a unified whole when seen from outside, but seen from inside, it becomes obvious that it consists of a whole number of individual trees and their differing relations to each other. In that sense, families are about unity and difference, and the proverb thinks through borders rather than in terms of either inside or outside a bordered space.

The narrative structure of the novel reinforces this sense of relation, proximity, and connection, but also of disparity, rupture, and movement. Each chapter of the novel can be seen as a self-contained short story, but if read in succession, the reader can also create connections and relations between the single chapters via cross-references to earlier protagonists and overarching motifs, creating an ongoing story across seven generations. Before starting the first chapter, the reader is confronted with a family tree (yet another metaphor taken from nature that ties in with the Akan proverb from the beginning). The

2 In the following, all quotes from the novel will be indicated by the shorthand $H G$ and a page number. 
tree starts with Maame, an Asante woman who is taken to a Fante tribe in a slave raid in the 1750s. She has one daughter, Effia, with the Fante man who is her slave owner, and escapes back to her tribe in a fire she has set herself in the night her daughter is born. As a free woman, she marries and has a second daughter, Esi. The two half-sisters will never meet in the novel, and Effia does not even know that she has a sister.

This initial construction of one woman who has two daughters in two places who share genetic ancestry but never meet each other is an obvious device to think through ideas of home, family, and belonging. The mother literally and metaphorically is the origin and first home of each child, yet their experiences of home and their life trajectories are vastly different. In Maame and her two daughters, the novel asks questions about nature and nurture. It shows that both Effia and Esi desire to feel at home, primarily through their attachment to a mother. Yet, for both of them, Maame cannot be an unconditional, uncomplicated home: for Effia, because she will never know Maame, who leaves her at birth, and for Esi, because Maame's traumatic past has made her unable to simply return and be at home. As Esi realises in her chapter:

Maame was not a whole woman. There were large swaths of her spirit missing, and no matter how much she loved Esi, and no matter how much Esi loved her, they both knew in that moment that love could never return what Maame had lost. $(H G, 42)$

Through her captivity and loss of a child, Maame has also lost her belief in home as unconditional, organic, or safe. The broken families that start off the novel are therefore a stark contrast to the idyllic image of George Hicks' Old England and the fated union of white husband and wife in front of their tidy home.

It is thus no coincidence that Maame is the only character in the family tree without their own chapter. She figures in her daughter Esi's story, but her own story is never told in full. We do not know where she came from and we do not know where her story ends because even her death remains uncertain. She is a point of origins and the beginning of the family tree (and the novel) without ever being a real presence, but even her absence is a matter of many of the protagonists' homing desires. As such a desired point of origins, she haunts most of the following chapters. As Gyasi formulates at the beginning of Effia's chapter, Maame is like the fire that she has started:

The night Effia Otcher was born into the musky heat of Fanteland, a fire raged through the woods just outside her father's compound. [...] it burned, up and through, unconcerned with what wreckage it left behind, until it reached an Asante village. There, it disappeared, becoming one with the night. $(H G, 3)$

In that sense, Maame as the story's initial mother and point of origins turns into a metaphor for home connected to sedentarist ideas about genetic belonging and organic proximity, and both Effia and Esi more or less consciously yearn for her. At the same time, however, her absence, fragmented identity, and flight connect her to mobility and a continuing homelessness and spiritual migrancy that Esi describes as "not being a whole woman" $(H G, 42)$.

In the very different fates of each branch of the family tree, the question of routes and roots and the ambivalence of Maame's absence and presence is then taken up again. In Effia, Maame's inability to really be at home becomes most prominent, making Effia's story a prime example of the pitfalls of sedentarist discourse. Esi's story, on the other hand, shows that movement and homelessness are equally ambivalent and that mobility is not necessarily liberating as nomadological discourses have claimed. While Effia marries the British governor in charge of Cape Coast Castle and the British slave trade, her half-sister Esi is sold as a slave to America after being held captive in the dungeons below. For my following close reading, I concentrate on the first two chapters describing Effia's and Esi's stories, because their fates illustrate Gyasi's assessment of home as sedentarist presence and nomadological absence, as both positive and negative, as something lost and never in existence.

\section{Making Yourself Small: Effia's Home as Non-Belonging}

Effia's story begins with her troubled relationship to Baaba, first wife of her father, who later turns out not to be her birth mother, as Effia thinks, but 
her foster mother. Baaba hates and beats Effia from birth although Effia does not understand or even ask why. For each violent assault on her foster child, Baaba is punished by her husband, Effia's genetic father and the previous slave owner of Maame. The cyclical violence paradoxically connects Effia, her father, and Baaba: "For each scar on Effia's body, there was a companion scar on Baaba's, but that didn't stop mother from beating daughter, father from beating mother." $(H G, 5)$. Much in line with sedentarist imaginaries of home and family, a naturalised hierarchy of genders and generations is here put into practice that is typical of the idealised communal relations so cherished by many nationalist discourses and visualised in Hick's watercolour: the husband as the head of the household rules the wife, while the mother rules the children. In tune with this naturalised sense of hierarchy, the passage then presents family connections as intense bodily, organic connections, here taking the shape of the doubled scars, but these bodily connections do not create positive, organic experiences of belonging together. Rather, the scars and the hierarchies connecting the generations and genders outline the trauma and disjunction within the space of the home and the implicit violence of sedentarist ideals of home in general. The family home is a space of rejection although Effia never questions that she belongs there or that Baaba is her mother. She simply takes 'home' and 'family' as she knows it for granted, and she embodies this home not only in her scars, but also in her self-image: "It was only when Effia didn't speak or question, when she made herself small, that she could feel Baaba's love, or something like it." $(H G, 8)$. Home is smallness, silence, and a desperate attempt to come up to the unspoken, yet crucial and unquestioned expectations of the rules and people closest to Effia.

The first time that Effia starts to question her sense of home is when a white British soldier comes to her village to propose to one of the local girls. As the white man is shown around the place, he does not understand community relations, family arrangements, or the function of the village huts:

They stopped first by Effia's own compound. "This is where we live," Effia told the white man, and he smiled at her dumbly, his green eyes hidden in fog. He didn't understand. Even after his translator spoke to him, he didn't understand. Cobbe held Effia's hand as he and Baaba led the white man through the compound. "Here, in this village," Cobbe said, "each wife has her own hut. This is the hut she shares with her children. When it is her husband's night to be with her, he goes to her in her hut." The white man's eyes grew clearer as the translation was given, and suddenly Effia realized that he was seeing through new eyes. The mud of her hut's walls, the straw of the roof, he could finally see them. [...] Effia forced herself to see things through new eyes, too. She smelled the sea-salt wind as it touched the hairs in her nose, felt the bark of a palm tree as sharp as a scratch, saw the deep, deep red of the clay that was all around them. $(H G, 6)$

Showing her home to someone from another cultural context makes Effia reassess the routines and practices of her family. Just as the white man can only 'see' the huts when he is made to understand how social relations and family practices work in the Fante village, Effia can, for the first time, really 'see' her home and her family. Through a stranger becoming more familiar with her homeplace, Effia can start to de-familiarise her sense of home and begin to question what she has taken for granted. This de-familiarisation is again expressed through bodily experiences like smell or touch. Just as her scars have become the embodiment of the abusive relation to her mother and the violence of home, her body here can become the medium to start generating new ideas of home apart from those Effia has learnt to accept as organic and natural.

This process of de-familiarisation continues with Effia's marriage to Governor James Collins. Her father strongly resists the idea of his daughter marrying a white man, but her mother is more than keen on Effia leaving the village. While her father cries when she leaves, Baaba is relieved to be rid of the child she has been forced to take care of. The present of the black stone that Baaba gives to Effia when she leaves is thus an ambivalent one: "She slipped it into Effia's hands and then leaned into her until her lips were touching Effia's ear. 'Take this with you when you go,' Baaba said. 'A piece of your mother.'" $(H G, 16)$. In a first reading, the present of the stone and the intimate bodily touch seem like tender gestures and a request to take a piece of Baaba to remember her by. However, the reader later finds out that Maame is Effia's birth mother and that the stone belonged to her. 
Baaba's act of giving Maame's stone to Effia must thus be reinterpreted as a final purge of Maame's presence in the Fante community and in Cobbe's family. In the course of the novel, many seemingly obvious or familiar acts like this giving of a present have to be reassessed, making readers aware of their own assumptions about home as comfort and safety, family, love, or bodily touch. Like in a crime novel, the second reading changes our assessment of such situations and makes us aware that our intuitive first assumptions, often shaped by sedentarist ideals about home, were wrong. Home is thus effectively de-familiarised for both Effia and the reader.

When Effia is taken to live in the Castle with James Collins, this critical reassessment of home as organic belonging is reinforced even more strongly. Although Effia still uses the practices of her homeplace as an epistemological framework to make sense of her new surroundings, for example by describing the Castle as a village ( $H G$, 17), she knows that the place where she comes from has been no space of belonging for her. This becomes clear in the confrontation between Effia and James after she hears crying from the dungeons and finds out that people are held captive in the castle:

\footnotetext{
"You white people. My father warned me about your ways. Take me home. Take me home right now!" [...] "You want to go home?" James asked. His Fante firm, though unclear. "Your home is no better." Effia pulled his hand from her mouth and stared at him for a while longer. She remembered her mother's joy at seeing her leave, and knew that James was right. She couldn't go home. (HG, 17)
}

This passage has several levels when it comes to notions of home. Firstly, it implies that Effia comes from a space that she calls home and that she has a desire to return to. It then becomes clear that this home has been lost to her: she cannot go home. But Effia's story goes even further: her memory of her mother's joy in seeing her leave makes the reader and Effia realise that home did not exist in the first place, and this is again embodied by a mother figure who contradicts traditional ideas of mothers as origins, roots, and organic belonging. Both her birth mother Maame, who left her at birth, and her foster mother Baaba, who was keen to get rid of her, are unavailable for Effia as points of origin, comfort, and belonging.
Although Effia has been part of the village community and has had a home in terms of shelter, food, and close relations, and although she is later loved by her white husband and accepts the Castle as her new place of residence, an essential, 'natural' sense of home is something that is and has always been missing from Effia's life, as sedentary and geographically stable as it is.

Effia's chapter ends with her pregnancy by James Collins, her father's death, and the revelation that Baaba is not her mother. In a foreshadowing of many of the novel's characters' sense of non-belonging, Baaba curses her foster daughter: "'You are nothing from nowhere. No mother and now no father.' She looked at Effia's stomach and smiled. 'What can grow from nothing?'" (HG, 27). Effia will be a mother, but even at that early stage, it is obvious that her children and all her further descendants will suffer from a sense of loss and unrest, just as much as feeling a desire for home as a place of wholeness.

\section{Being Moved towards Loss: Esi's Involuntary Migrancy}

In stark contrast to Effia's chapter, in which even the journey between the village and the Castle is not depicted or even commented upon, as if Effia were simply transplanted from the one place to the other, Esi's chapter mostly consists of scenes in which the main protagonist moves from one place to another, either literally or in her mind's eye. However, I will show that these forms of mobility are not connected to a liberatory movement or a progressive nomadology, but rather as lacking in agency and leading towards the final fate of slavery and deportation that will later shape all of Esi's descendants' lives and sense of homelessness in America.

The chapter begins in the dungeons below the British Cape Coast Castle where Esi has spent the previous two weeks after being taken from her village in a Fante slave raid. Although most of the chapter's story time is spent in this dungeon, the chapter's discourse mostly concentrates on how Esi came to be there. The dungeon is a transitional space, a non-home or even non-place for Esi and her fellow captives, in which they are held for a specific, yet unknown time, and from 
which they are taken to yet another unknown non-home. Just like Esi's own sense of time and place, the chapter is therefore split into "Now" and "Before the Castle" (HG, 31), which is Esi's only way of dealing with the traumatic loss of her home, the conditions of life in the dungeons, and the uncertainty of what will happen to her.

A sense of the future does not exist except for images of a future that Esi would have had if she had been allowed to remain in her community: "Esi would have married [...] in the summer, when the sun stretched long and high, when the palm trees could be tapped for wine" (HG, 28, emphasis mine). This use of the modal 'would have' as a third conditional works like a time machine because it expresses a potential future event in terms of the past tense and, in effect, as a lost opportunity of the present. Although the 'if' is missing in the sentence (as, for example, by adding, "if she had not been captured, she would have..."), this 'if' is looming in the background of the whole paragraph, framing every single memory of her childhood, her home, and her family. The bliss and the happiness of her childhood days is therefore shown as irrevocably lost, annihilating not only Esi's social connections and her home, but also her own sense of self in terms of a personal future. This loss even includes her memories themselves:

When she wanted to forget the Castle, she thought of these [happy] things, but she did not expect joy. Hell was a place of remembering, each beautiful moment passed through the mind's eye until it fell to the ground like a rotten mango, perfectly useless, uselessly perfect. $(H G, 28)$

Her past and her future, in their connection to a blissful home and close community, are elusive and unhelpful, yet the present is so unbearable that Esi cannot face it without resorting to memories of the past and images of a lost future.

In tune with this emphasis on the irrevocable loss of home and with it, a sense of self and stability, the chapter is dominated by verbs of movement, first and foremost "walk," "travel," "pass (through)," and "move." However, most of these verbs are used to stress the passivity and lack of agency of the people who are moved, mostly against their will. The food Esi is given in the dungeons "passed right through her" (HG, 29), and someone else's urine or her own blood 'travel' between her legs (cf. $H G, 31,48$ ). Later on, water "slip[s] out of her numb lips" $(H G, 47)$. Such expressions of movement give more agency to the substances travelling than to the people experiencing or rather enduring this movement, inverting the agency and selfhood of subjects and objects and foreshadowing the life of slavery ahead of Esi, in which she and her children will be objects to be bought and sold.

This sense of involuntary movement is reinforced by the depiction of actual travel in Esi's chapter. While she loves to walk across the village with her father as a child (cf. $H G, 31 f$.), the most intense description of travel is the long walk to the Cape Coast Castle after she is captured by the slave traders:

She was tied to others; how many, she didn't know. [...] Esi studied the lines in [her] palms. They led nowhere. She had never felt so hopeless in her life. Everyone walked. Esi had walked for miles with her father before and so she thought that she could take it. And indeed the first few days were not so bad, but by the tenth the calluses on Esi's feet split open and blood seeped out, painting the leaves she left behind. Ahead of her, the bloody leaves of others. (HG, 43)

In this passage, walking turns into a movement without agency or destination, and even the lines in Esi's palms, in spite of their closeness and familiarity, tell her nothing about her future or her destiny. The once homely and blissful activity of walking that she used to enjoy when spending time with her father, becomes painful and unending and mirrors the loss of home and selfhood that Esi experiences. As the other captives, she is turned into one among many anonymous objects in a long line of trading goods, tied to each other and mixing their blood on the path towards slavery. Even the social ties that Esi creates on that journey with another woman called Tansi are fleeting and transitory. Tansi is therefore called Esi's "journey friend," and Esi does not dare to hope that "they would be allowed to stay together even longer" (HG, 29). After Esi is raped by a British soldier, she does not even want to keep up the ties to Tansi but starts to "separate herself" from the time and place she is in: "She no longer wanted to talk to Tansi. She no longer wanted to listen to stories." (HG, 48). The experience of involuntary movement and the loss of family and social ties has effectively destroyed Esi's sense of community and home, making her heart the "gray 
rock" that her daughter Ness in a later chapter associates with her and creating the "hardness of spirit" that will make Esi unable to even reach for her daughter when the child is taken from her and sold to another plantation ( $H G, 71)$.

This loss of home and its ensuing literal and spiritual homelessness is not liberating towards a new nomadic subjectivity, and it does not enable resistance to institutions or state control, as a radical nomadology would have it. Rather, it subordinates Esi to power structures out of her control and makes her vulnerable to what, at the very end of the chapter, is called "more evil [that] was coming with the next wave" (HG, 49). Even the movement of the waves is more active in its foreboding anticipation than Esi and her fellow captives, who are 'being herded' and 'being marched' across the sand towards the next involuntary journey across the infamous Middle Passage (cf. $H G$, 49).

\section{Conclusion}

Home is a contested concept that has been seen as stable and fluid, bounded and open, negative and positive. While sedentarist discourses stress the presence, stability, and boundedness of home and present social relations within the home as organic, natural, and in need of defence, nomadological views re-assess home as reactionary, non-existent, and a phantasy of origins used to authenticate repressive state control and violent action against anyone deemed Other. This entails different views towards mobility and movement, making it threatening and pathological in a sedentarist metaphysics, while being praised as liberating and progressive by nomadology. This binary opposition of essentialising or rejecting home and the often reductive notions of mobility, fluidity, and selfhood attached to these oppositions tend to overlook the ambivalence of notions of home as a place, an imaginary, a sense of self, communal ties, affects and feelings, as well as practices.

Home is an absence, elusive, and constantly in the making, but it also is an aspiration. In contrast to both sedentary and nomadological ideas on home, terms like Avtar Brah's 'homing desire' stress that humans have a craving for belonging, but that this might not be attached to a real place or even be attainable in the first place. It is this experience of losing something that was not there, of wanting to belong and desiring the safety and comfort of an idealised home, which the protagonists of Homegoing go through. The absent-present mother Maame and her two daughters embody this ambivalent sense of home as intensely desired but also as always already lost and problematic. As my close readings have shown, Maame's dual and complex experience with two homes and two daughters makes her daughter Effia accept a sedentary notion of home although it is shaped by violence and self-rejection, while Esi's happy childhood home is, again violently, interrupted by capture and involuntary movement that defy nomadological celebrations of liberatory mobility. The novel thus problematises easy notions of organic belonging and of home as a self-evident fact of nature as much as it complicates ideas about a homeless flux of ontological migrancy. As the novel's title indicates, home is a process and an aspiration, a constant 'home-going,' not a home-coming, home-being, or an eternal homelessness.

\section{Works Cited}

Gyasi, Yaa (2016): Homegoing. London: Viking.

Ahmed, Sara (1999): Home and Away. Narratives of Migration and Estrangement. In: International Journal of Cultural Studies, 2/3, p. 329-347.

Ahmed, Sara (2000): Strange Encounters. Embodied Others in Post-Coloniality. London: Routledge.

Ahmed, Sara/Castañeda, Claudia/Fortier, Anne-Marie/ et al. (eds.) (2003): Uprootings/Regroundings. Questions of Home and Migration. Oxford: Berg.

Al-Ali, Nadje/Koser, Khalid (2002): New Approaches to Migration? Transnational Communities and the Transformation of Home. London: Routledge.

Anderson, Benedict (2006): Imagined Communities. London: Verso.

Bauman, Zygmunt (22012): Liquid Modernity. Cambridge: Polity.

Blunt, Alison/Dowling, Robyn (2006): Home. London: Routledge.

Bowlby, Sophie/Gregory, Susan/McKie, Linda (1997): 'Doing Home.' Patriarchy, Caring, and Space. In: Women's Studies International Forum, 20/3, p. 343-350.

Brah, Avtar (1996): Cartographies of Diaspora. Contesting Identities. London: Routledge. 
Braidotti, Rosi (22011): Nomadic Subjects. Embodiment and Sexual Difference in Contemporary Feminist Theory. New York: Columbia UP.

Clifford, James (1997): Routes. Travel and Translation in the Late Twentieth Century. Cambridge, Mass.: Harvard UP.

Cunningham, D. Joseph/ Pfeiffer, Peter C./RyshinaPankova, Marianna (2018): Assessing Humanities Learning in an Integrated Undergraduate German Curriculum. In: Die Unterrichtspraxis/Teaching German, 51/2, p. 144-155.

Deleuze, Gilles/Guattari, Félix (1987): A Thousand Plateaus. Capitalism and Schizophrenia. Transl. Brian Massumi. London: continuum.

Fox, Michael Allen (2016): Home. A Very Short Introduction. Oxford: UP.

George, Rosemary Marangoly (1996): The Politics of Home. Postcolonial Relocations and Twentieth-Century Fiction. Cambridge: UP.

Gilroy, Paul (1993): The Black Atlantic. Modernity and Double Consciousness. London: Verso.

Grossberg, Larry (1996): The Space of Culture, the Power of Space. In: Chambers, Iain/Curti, Lidia (eds.): The Post-colonial Question. Common Skies, Divided Horizons. London: Routledge, p. 169-188.

Heidegger, Martin (1975): Building Dwelling Thinking. In: Heidegger, Martin: Poetry, Language, Thought. Transl. Albert Hofstadter. New York: Harper Colophon Books, p. $141-160$.

Hicks, George (1857): The Sinews of Old England. Watercolour. Yale Center for British Art, Friends of British Art Fund. http://collections.britishart.yale.edu/ vufind/Record/3659731. Public Domain Image. Last accessed: 11 April 2019.

Hofstadter, Albert (1975): Introduction. In: Heidegger, Martin: Poetry, Language, Thought. Transl. Albert Hofstadter. New York: Harper Colophon Books, p. ix-xxii.

Hollander, John (1991): The Idea of a Home: A Kind of Space. In: Social Research, 58/1, p. 31-49.

King, Russell (2016): Afterword: Many Ageings, Multiple Migrations and Ambiguous Homes. In: Walsh, Katie/
Näre, Lena (eds.): Transnational Migration and Home in Older Age. London: Routledge, p. 239-252.

Loomba, Ania (2002): Shakespeare, Race and Colonialism. Oxford: Oxford UP.

Mallett, Shelley (2004): Understanding Home. A Critical Review of the Literature. In: The Sociological Review, 52/1, p. 62-89.

Marston, Sallie A. (2000): The Social Construction of Scale. In: Progress in Human Geography, 24/2, p. 219-242.

McClintock, Anne (1997): 'No Longer in a Future Heaven.' Gender, Race and Nationalism. In: Mufti, Aamir/ Shohat, Ella/McClintock, Anne (eds.): Dangerous Liaisons. Gender, Nation, and Postcolonial Perspectives. Minneapolis: University of Minnesota Press, p. 89-112.

Morley, David (2000): Home Territories. Media, Mobility and Identity. London: Routledge.

Morley, David (2003): What's 'Home' got to do with it? Contradictory Dynamics in the Domestication of Technology and the Dislocation of Domesticity. In: European Journal of Cultural Studies, 6/4, p. 435-458.

Morley, David (2017): Communications and Mobility. The Migrant, the Mobile Phone, and the Container Box. Hoboken, NJ: Wiley-Blackwell.

Nail, Thomas (2015): The Figure of the Migrant. Stanford: UP.

Porteous, J. Douglas/Smith, Sandra E. (2001): Domicide. The Global Destruction of Home. Montreal: McGillQueen's UP.

Tabor, Philip (1998): Striking home - the Telematic Assault on Identity. In: Hill, Jonathan (ed.): Occupying Architecture. Between the Architect and the User. London: Routledge, p. 217-228.

Tuan, Yi-Fu (2012): Epilogue. Home as Elsewhere. In: Kugele, Jens/Eigler, Friederike Ursula (eds.): 'Heimat': At the Intersection of Memory and Space. Berlin: De Gruyter, p. 226-239.

Wolters, Eugene (2015): The Figure of the Migrant, an Interview with Thomas Nail. Critical Theory: http:// www.critical-theory.com/the-figure-of-the-migrantan-interview-with-thomas-nail/ Last accessed: 10 April 2019. 